23 Nopember 2015

12:45

Yanis Page 1 


\title{
HUBUNGAN INTELEGENSI DAN MOTIVASI DENGAN PRESTASI BELAJAR MAHASISWA S1 KEPERAWATAN STIKES YAYASAN RS ISLAM SURABAYA
}

\author{
Yanis Kartini \\ (Stikes Yarsis, Jl. SMEA 57 Surabaya) \\ email: sinay65@yahoo.com
}

\begin{abstract}
There are many factors which affect the academic achievement: internal and external factors. The internal factors include the physical and psychological factors (interest, intelligence, motivation, attention, readiness, and maturity). In academic year of 2011/2012, STIKes Yarsis has added one test, the psychological test, to determine the candidates to pass the student's admission test. So far, the data haven't been managed as the important information for the educational management. Therefore, the purpose of this study was to find out the bivariate and multivariate correlation between intelligence and motivation toward the student's academic achievement. The design of study was analyticcross sectional. The population involved the students of Program of Study of S-l in the academic year 2011/2012. 106 respondents were chosen as the samples by using simple random sampling technique. The independent variable was the level of intelligence and motivation, whereas the dependent variable was the academic achievement. The data collection was done by using secondary data, which were then analyzed by using simple and multiple linear regression tests. The result of study in bivariate correlation analysis showed that there was a correlation between intelligence and motivation toward the student's academic achievement. The independent variable playing a role in predicting the GPA (grade-point average) was motivation $(\mathrm{p}=0.028)$. The value of R-Squared was 0.045 which meant that $4.5 \%$ of the academic achievement was affected by motivation, whereas the rest of them were affected by other factors. Moreover, the result of analysis described that GPA $=3.097+0.060 *$ motivation. In conclusion, in bivariate correlation analysis, intelligence and learning motivation had a correlation with academic achievement. In multivariate correlation analysis, intelligence didn't have any correlation with academic achievement, whereas motivation had correlation with academic achievement. Furthermore, academic achievement had a relationship with motivation (4.5\%), and the rest of them had a correlation with other factors, such as campus environment, learning media, curriculum, lecturers, social support, etc.
\end{abstract}

Keywords: intelligence, motivation, academic achievement

\begin{abstract}
Abstrak: Banyak faktor yang mempengaruhi prestasi belajar, yaitu faktor intern dan faktor ekstern. Faktor intern meliputi fisik dan psikologi (minat, intelegensi, bakat, motivasi, perhatian, kesiapan, kematangan). Pada tahun akademik 2011/2012 STIKes YARSIS menambah 1 tes untuk penentuan kelulusan mahasiswa baru yaitu dengan test psikologi. Sejauh ini data tersebut belum dikelola sebagai informasi yang penting untuk menajemen pendidikan. Penelitian ini bertujuan untuk mengetahui apakah ada hubungan intelegensi dan motivasi baik secara parsial maupun bersama terhadap prestasi belajar mahasiswa. Desain penelitian yang digunakan adalah analitik cross sectional. Populasi adalah mahasiswa prodi S1 keperawatan STIKes YARSIS Angkatan tahun 2011/2012. Besar sampel adalah 106 responden. Sampling yang digunakan simple random sampling. Variabel independen adalah tingkat intelegensi dan motivasi, variabel dependennya
\end{abstract}


prestasi belajar. Pengumpulan data menggunakan data skunder. Data dianalisis dengan uji regresi linier sederhana dan ganda, dengan $\alpha=0,05$. Hasil penelitian ini menunjukkan bahwa ada hubungan intelegensi dan motivasi dengan prestasi mahasiswa bila diuji secara parsial $(p=0,00$ dan 0,02$)$, namun bila diuji secara bersama, variabel independen yang berperan dapat memprediksi indek prestasi adalah motivasi $(\mathrm{p}=0,028)$. Dari nilai $\mathrm{R}$ square sebesar 0,045 , yang berarti bahwa $4,5 \%$ prestasi akademik dipengaruhi motivasi, dan sisanya dipengaruhi oleh faktor lain, dari uji tersebut diperoleh persamaan garis: IPK $=3,097+0,060 *$ motivasi. Secara parsial intelegensi dan motivasi belajar berhubungan secara signifikan dengan prestasi belajar. Secara bersama intelegensi tidak berhubungan, dan motivasi berhubungan dengan prestasi belajar. Prestasi belajar berhubungan 4,5\% dengan motivasi dan sisanya berhubungan dengan faktor lain, misalnya suasana dikampus, media pembelajaran, kurikulum, dosen, dukungan sosial dan lain-lain.

Kata Kunci : intelegensi, motivasi, prestasi belajar

\section{Pendahuluan}

Menghadapi era globalisasi sekarang ini, diperlukan peningkatan kualitas sumber daya manusia. Peningkatan ini terlebih dahulu dapat dilakukan dengan peningkatan mutu pendidikan nasional pada umumnya dan peningkatan prestasi akademik mahasiswa pada khususnya. Salah satu upaya yang telah dilakukan oleh sekolah tinggi ilmu kesehatan yayasan RS Islam Surabaya (selanjutnya disingkat STIKes YARSIS) dalam rangka meningkatkan mutu pendidikan adalah dengan cara selektif dalam sistem rekrutmen mahasiswa baru. Sistem seleksi yang dilakukan STIKes YARSIS pada awal berdiri (2006-2010), test seleksi meliputi persyaratan fisik berupa tinggi \& berat badan, test tulis untuk mengukur kemampuan kognitif peserta test yang berupa mata kuliah IPA terpadu, matematika, Bahasa Indonesia \& Bahasa Inggris, serta test kesehatan. Pada tahun akademik 2011/2012, ada perubahan sistem seleksi, yaitu untuk test tulis menggunakan test TPA dan ada penambahan berupa test psikologi. Namun, ternyata test psikologi tersebut belum dimanfaatkan secara maksimal dalam penentuan kelulusan peserta seleksi, karena masih ada $16 \%$ dari 140 peserta yang diterima "tidak disarankan" menjadi mahasiswa STIKes YARSIS.
Berdasar permasalahan tersebut diatas, peneliti ingin menganalisis hubungan faktor psikologi yaitu intelegensia dan motivasi dengan keberhasilan mahasiswa yang dinilai dari indeks prestasi akademik. Menurut Slameto (2003) bahwa keberhasilan seseorang dalam belajar dipengaruhi oleh dua faktor, yaitu faktor internal dan faktor eksternal. Faktor internal meliputi 1. Faktor fisik/jasmani (kesehatan dan cacat tubuh), 2. faktor psikologis (intelegensi, bakat, minat, perhatian, motivasi, kesiapan, kematangan), dan 3. faktor kelelahan (fisik dan mental). Faktor eksternal meliputi 1. lingkungan keluarga, 2. lingkungan sekolah, dan 3 . lingkungan masyarakat.

Intelegensi sebagai unsur kognitif dianggap memegang peranan yang cukup penting. Intelegensi sendiri dalam perspektif psikologi memiliki arti yang beraneka ragam. Salah satu yang paling pokok yaitu menurut Chaplin (dalam Syah, 2006) adalah kemampuan menyesuaikan diri dengan situasi baru secara cepat dan efektif atau kemampuan menggunakan konsep-konsep abstrak secara efektif. Motivasi juga berperanan penting dalam menentukan keberhasilan mahasiswa, sebagai dorongan mental yang menggerakkan dan mengarahkan perilaku 
manusia untuk belajar. Motivasi belajar timbul karena dua faktor yaitu faktor intrinsik, berupa keinginan untuk berhasil, dorongan kebutuhan belajar, dan harapan akan cita-cita. Motivasi interinsik bermakna sebagai keinginan dari diri sendiri untuk bertindak tanpa adanya rangsangan dari luar. Sedangkan faktor ekstrinsiknya adalah adanya penghargaan, lingkungan belajar yang kondusif, dan kegiatan belajar yang menarik (Nursalam, 2008). Menurut Slameto (2003) seringkali anak didik yang tergolong cerdas tampak bodoh karena tidak memiliki motivasi untuk mencapai prestasi sebaik mungkin. Seorang anak didik yang cerdas, apabila memiliki motivasi belajar yang rendah maka dia tidak akan mencapai prestasi akademik yang baik. Sebaliknya, seorang anak didik yang kurang cerdas, tetapi memiliki motivasi yang tinggi untuk belajar, maka dia akan mencapai prestasi akademik yang baik.

Pengukuran prestasi akademik dalam dunia pendidikan formal, adalah sangat penting. Sebagaimana diketahui, proses pendidikan formal adalah suatu proses yang kompleks yang memerlukan waktu, dana dan usaha serta kerjasama berbagai pihak. Berbagai aspek dan faktor terlibat dalam proses pendidikan secara keseluruhan. Tidak ada pendidikan yang secara sendirinya berhasil mencapai tujuan yang digariskan tanpa interaksi berbagai faktor pendukung yang ada dalam sistim pendidikan tersebut. Betapa jelasnya pun suatu tujuan pendidikan telah digariskan, tanpa usaha pengukuran maka akan mustahil hasilnya dapat diketahui. Keberhasilan program pendidikan dapat dinyatakan adanya suatu kemajuan dengan memberikan bukti peningkatan atau pencapaian yang diperoleh, salah satunya dengan mengetahui indeks prestasi mahasiswa.

Keberhasilan dalam menempuh studi adalah harapan setiap mahasiswa, pendidik, orang tua, juga penyelenggara pendidikan. Mahasiswa yang dapat menyelesaikan studi tepat waktu dan mendapatkan prestasi yang gemilang ditambah dengan soft skills yang memadai akan mampu bersaing disegala bidang. Pada akhirnya juga akan membawa nama harum institusi karena lulusannya dapat diterima dan diserap di dunia kerja, dan mendapatkan pekerjaan sesuai dengan profesinya, serta mendapatkan imbalan yang layak. Dengan demikian, sebagai penyelanggara pendidikan perlu untuk memperhatikan berbagai faktor yang dapat mempengaruhi keberhasilan mahasiswa, termasuk mencari solusi bagi mereka yang ternyata masih mendapatkan hasil belajar yang kurang memadai, terutama bagi mereka yang mengalami kesulitan belajar. Langkah yang dapat dilakukan antara lain dengan melakukan bimbingan dan konseling yang terstrukur dan menyenangkan.

Penelitian ini bertujuan mengetahui hubungan tingkat intelegensi dan motivasi belajar terhadap prestasi akademik pada mahasiswa program studi S1 keperawatan STIKes YARSIS.

\section{Metode}

Desain penelitian yang digunakan adalah analitik yang dilakukan secara cross sectional dimana pengukurannya variabel independen dan variabel dependen dilakukan pada waktu yang sama.

Populasi dalam penelitian ini adalah mahasiswa program studi S1 keperawatan angkatan tahun 2011/2012, sebesar 142 orang, sampel sebesar 106 responden diambil secara simpel random sampling. Data dikumpulkan dengan menggunakan data skunder yaitu berupa data hasil psikotest untuk mengetahui tingkat intelegensia dan motivasi responden, juga data indeks prestasi kumulatif untuk mengetahui prestasi belajar. Data diolah dengan cara editing, koding dan prosesing. Analisis data menggunakan regresi linier sederhana dan regresi linier ganda, dengan $\alpha=0,05$. Apabila $\rho<\alpha$, maka $\mathrm{H}_{0}$ ditolak, artinya ada hubungan 
antara intelegensi dengan prestasi belajar dan ada hubungan antara motivasi dengan prestasi belajar. Dan jika intelegensi dan motivasi keduanya ada hubungan dengan prestasi belajar, akan dilanjutkan dengan uji regresi linier ganda, untuk melihat apakah kedua variabel independen tersebut saling mempengaruhi.

\section{Hasil dan Pembahasan}

\section{a. Hasil}

Pada bagian ini disajikan data dari variabel yang diukur yaitu intelegensia dan motivasi dengan prestasi belajar. Hasil yang didapatkan adalah sebagai berikut :

1) Distribusi tingkat intelegensia dan prestasi belajar

Distribusi tingkat intelegensia dan prestasi belajar (IPK) dapat dilihat pada tabel 1

Tabel 1. Distribusi responden berdasarkan tingkat intelegensi dan prestasi belajar (IPK) tahun 2013

\begin{tabular}{llll}
\hline Variabel & Mean & SD & Min-Mak \\
\hline 1. Tingkat IQ & 99,10 & 6,809 & $85-114$ \\
2. IPK & 3,30 & 0,236 & $2,60-3.9$ \\
\hline
\end{tabular}

Pada tabel 1 dapat dijelaskan bahwa rata-rata tingkat intelgensi responden adalah 99.10, dengan standart deviasi 6,809. Tingkat intelegensi terendah adaah 85 dan tertinggi adalah 114.

Rata-rata indek Prestasi responden adalah 3,30, dengan standar deviasi 0,236 . Indeks prestasi terendah adalah 2,60 dan tertinggi 3,95.

2) Distribusi responden berdasarkan motivasi berprestasi

Distribusi frekwensi responden berdasarkan motivasi berprestasi dapat dilihat pada tabel 2
Tabel 5.4. Distribusi responden berdasarkan tingkat motivasi pada tahun 2013

\begin{tabular}{cccc}
\hline No & Motivasi & Frekuensi & Persentase (\%) \\
\hline 1 & Belum & 53 & 50.0 \\
2 & $\begin{array}{c}\text { Memadai (3) } \\
\text { Cukup kuat }\end{array}$ & 47 & 44.3 \\
& $\begin{array}{c}\text { (4) } \\
3\end{array}$ & 6 & 5.7 \\
\hline & Kuat (5) & 106 & 100.0 \\
\hline
\end{tabular}

Pada tabel 2 dapat dijelaskan bahwa dari 106 responden, setengah $(50 \%)$ responden mempunyai motivasi yang belum memadai (tingkat 3 dari 6 tingkatan) untuk mencapai prestasi.

3) Hubungan tingkat intelegensi dengan indeks prestasi

Hubungan tingkat intelegensia dengan indeks prestasi dapat dilihat pada tabel 3

Tabel 5.5. Analisis korelasi dan regresi tingkat intelegensia dengan indeks prestasi responden tahun 2013

\begin{tabular}{|c|c|c|c|c|}
\hline Variabel & $\mathrm{r}$ & $\mathrm{R}^{2}$ & $\begin{array}{l}\text { Persamaan } \\
\text { garis }\end{array}$ & $\begin{array}{c}\mathrm{P} \\
\text { value }\end{array}$ \\
\hline $\begin{array}{l}\text { Tingkat } \\
\text { intele- } \\
\text { gensia }\end{array}$ & 0,35 & 0,13 & $\begin{array}{l}\mathrm{IPK}=2,084 \\
+0,012 * \mathrm{IQ}\end{array}$ & 0,000 \\
\hline
\end{tabular}

Hubungan tingkat intelegensi dengan indeks prestasi menunjukkan adanya hubungan yang signifikan $(\mathrm{p}=$ $0,000)$, dengan tingkat hubungan sedang $(\mathrm{r}=0,354)$, berpola positif yang berarti semakin tinggi nilai intelegensia, semakin tinggi indeks prestasi. Dari nilai koefisien determinasi $\mathrm{R}=0,126$ yang berarti persamaan garis regresi yang diperoleh dapat menerangkan $13 \%$ variasi indeks prestasi.

4) Hubungan motivasi dengan indeks prestasi

Hubungan tingkat motivasi dengan indeks prestasi dapat dilihat pada tabel 4 
Tabel 4. Analisis korelasi dan regresi tingkat motivasi dengan indeks prestasi responden tahun 2013

\begin{tabular}{|c|c|c|c|c|}
\hline Variabel & $\mathrm{R}$ & $\mathrm{R}^{2}$ & $\begin{array}{l}\text { Persamaan } \\
\text { garis }\end{array}$ & $\begin{array}{c}\mathrm{P} \\
\text { value }\end{array}$ \\
\hline $\begin{array}{l}\text { Tingkat } \\
\text { Motivasi }\end{array}$ & 0,30 & 0,092 & $\begin{array}{l}\text { IPK }=2,88+ \\
0,119^{*} \\
\text { Motivasi }\end{array}$ & 0,002 \\
\hline
\end{tabular}

Hubungan tingkat motivasi dengan indeks prestasi menunjukkan adanya hubungan yang signifaikan $(\mathrm{p}=0,002)$, dengan tingkat hubungan sedang $(\mathrm{r}=$ 0,303 ), berpola positif yang berarti semakin tinggi motivasi, semakin tinggi indeks prestasi. Dari nilai koefisien determinasi 0,092 yang berarti persamaan garis regresi yang diperoleh hanya dapat menerangkan $9,2 \%$ variasi indeks prestasi.

5) Hubungan intelegensi dan motivasi dengan indeks prestasi dianalisis bersama.

Hubungan tingkat intelegensi dan tingkat motivasi dengan indeks prestasi diuji bersama-sama dapat dilihat pada hasil uji multivariate (Regresi linier ganda).

Hasil uji dapat dijelaskan bahwa setelah dianalisis dengan metode Backward, ternyata variabel independen yang berperan dapat memprediksi indeks prestasi adalah motivasi $\mathrm{p}=0,028<\alpha(0,05)$. Pada nilai $\mathrm{R}$ menunjukkan nilai 0,045 artinya model regresi yang diperoleh hanya dapat menjelaskan $0,45 \%$ variable indeks prestasi.

Pada Hasil Coefisient dapat diperoleh persamaan garis sebagai berikut:

IPK $=3,097+0.060 *$ motivasi

Sebagai contoh apabila nilai motivasi didapatkan $=6$, maka IPK nya adalah:

$$
3,097+0,060 * 6=\mathbf{3 , 4 6}
$$

\section{b. Pembahasan}

1). Hubungan Intelegensi dengan Prestasi Hasil uji korelasi dan regresi diperoleh untuk menguji adanya hubungan tingkat intelegensi dengan indeks prestasi diperoleh hasil $\mathrm{p}=0,000<$ $\alpha$ maka Ho ditolak yang berarti menunjukkan adanya hubungan yang signifaikan antara tingkat intelegensi dengan indeks prestasi. Tingkat hubungan sedang $(r=0,354)$, berpola positif yang berarti semakin tinggi nilai intelegensia, semakin tinggi indeks prestasi. Dari nilai koefisien determinasi $\mathrm{R}=0,126$ yang berarti persamaan garis regresi yang diperoleh dapat menerangkan $12,6 \%$ variasi indeks prestasi.

Intelegensi menurut Azwar (2004) merupakan salah satu faktor internal yang mempengaruhi prestasi akademik seseorang, namun dari hasil penelitian tersebut ternyata intelegensi hanya berhubungan sekitar 12,6\% menentukan indek prestasi responden, berarti yang $87,4 \%$ dipengaruhi oleh faktor lain, baik dari kondisi fisik, atau kondisi psikologis dari unsur yang lain misalnya minat, motivasi, perhatian, maupun dari faktor eksternal seperti lingkungan keluarga, lingkungan sekolah (kurikulum, lingkungan belajar, metode pembelajaran dan lain-lain) ataupun lingkungan masyarakat juga ikut berperan dalam menentukan keberhasilan seseorang.

Menurut Slameto (2003) bahwa prestasi belajar dipengaruhi oleh dua faktor, yaitu faktor internal dan faktor eksternal. Faktor internal meliputi: 1. Faktor fisik/jasmani (kesehatan dan cacat tubuh), 2. faktor psikologis (intelegensi, bakat, minat, perhatian, motivasi, kesiapan, kematangan), dan 3. faktor kelelahan (fisik dan mental). Faktor eksternal meliputi 1. lingkungan keluarga, 
2. lingkungan sekolah, dan 3. lingkungan masyarakat.

b). Hubungan Motivasi dengan prestasi Berdasarkan hasil uji korelasi regresi diperoleh adanya hubungan yang signifaikan $(p=0,002)$, antara motivasi dan indeks prestasi dengan tingkat hubungan sedang $(r=0,303)$, berpola positif yang berarti semakin tinggi motivasi, semakin tinggi indeks prestasi. Dari nilai koefisien determinasi 0,092 yang berarti persamaan garis regresi yang diperoleh hanya dapat menerangkan $9,2 \%$ variasi indeks prestasi.

Menurut Slameto (2003) bahwa motivasi erat sekali hubungannya dengan tujuan yang akan dicapai dalam belajar, di dalam menentukan tujuan itu dapat disadari atau tidak, akan tetapi untuk mencapai tujuan itu perlu berbuat, sedangkan yang menjadi penyebab berbuat adalah motivasi itu sendiri sebagai daya penggerak. Hasil penelitian menunjukkan bahwa faktor motivasi hanya berhubungan sekitar $9,2 \%$ untuk prediksi atau penentuan indeks prestasi, berarti masih banyak faktor lain yang mempengaruhi, yaitu faktor eksternal antara lain lingkungan keluarga, lingkungan sekolah/kampus dan lingkungan masyarakat.

Menurut Slameto (2003) bahwa prestasi belajar dipengaruhi oleh dua faktor, yaitu faktor internal dan faktor eksternal. Faktor internal meliputi 1. Faktor fisik/jasmani (kesehatan dan cacat tubuh), 2. faktor psikologis (intelegensi, bakat, minat, perhatian, motivasi, kesiapan, kematangan), dan 3. faktor kelelahan (fisik dan mental). Faktor eksternal meliputi 1. lingkungan keluarga, 2. lingkungan sekolah, dan 3. lingkungan masyarakat

c). Hubungan intelegensi dan motivasi dengan prestasi

Hasil uji regresi linier ganda untuk mengetahui apakah intelegensi dan motivasi saling berhubungan/ mempengaruhi dalam penentuan indeks prestasi, ternyata setelah dianalisis dengan metode Backward dapat dijelaskan bahwa, variabel independen yang berperan dapat memprediksi indeks prestasi adalah motivasi $\mathrm{p}=0,028<\alpha(0,05)$. Jadi setelah diuji bersama, faktor intelegensi tidak berpengaruh pada prediksi/penentuan terhadap indeks prestasi.

Pada nilai $\mathrm{R}$ menunjukkan nilai 0,045 artinya model regresi yang diperoleh hanya dapat menjelaskan $4,5 \%$ variabel indeks prestasi, berarti faktor internal berupa psikologi (intelegensi dan motivasi) hanya berhubungan/berpengaruh sekitar $4,5 \%$, berarti pengaruhnya kecil sekali untuk menentukan indek prestasi atau keberhasilan belajar.

Berdasarkan hasil penelitian tersebut, kita perlu untuk meneliti faktor lain yang mempengaruhi prestasi belajar terutama pada faktor eksternal, karena dari faktor internal khususnya psikologi ternyata hubungannya masih relatif kecil yaitu sekitar $4,5 \%$, berari masih ada $95,5 \%$ dipengaruhi oleh faktor yang lain. Menurut Slameto (2003) bahwa prestasi belajar dipengaruhi oleh dua faktor, yaitu faktor internal dan faktor eksternal. Faktor internal meliputi 1. Faktor fisik/jasmani (kesehatan dan cacat tubuh), 2. faktor psikologis (intelegensi, bakat, minat, perhatian, motivasi, kesiapan, kematangan), dan 3. faktor kelelahan (fisik dan mental). Faktor eksternal meliputi 1. lingkungan keluarga, 2. lingkungan sekolah, dan 3. lingkungan masyarakat

\section{Penutup}

\section{Simpulan}

a. Mahasiswa Program Studi S1 Keperawatan STIKes YARSIS angkatan tahun 2011/2012 mempunyai rata-rata tingkat intelegensi 99,10, mempunyai motivasi kurang memadai untuk berhasi (tingkat 3), mempunyai ratarata indeks prestasi 3,30 . 
b. Ada hubungan signifikan antara intelegensi dan motivasi dengan prestasi belajar, tingkat hubungan sedang.

c. Motivasi dapat menjadi prediksi terhadap prestasi belajar setelah diuji bersama dengan intelegensi

\section{Saran}

a. Bagi Pendidik:

1) Motivasi mahasiswa perlu ditingkatkan agar dapat mencapai hasil/prestasi belajar yang maksimal.

2) Dalam proses pembelajaran perlu memperhatikan faktor individual mahasiswa agar perlakuan yang diberikan mahasiswa sesuai dengan ciri/kebutuhan mahasiswa guna membantu keberhasilan mereka dalam menempuh studi.

b. Bagi Peneliti selanjutnya:

Perlu meneliti faktor lain yang berhubungan dengan prestasi belajar, terutama faktor eksternal, baik lingkungan kampus maupun lingkungan keluarga mahasiswa.

\section{Daftar Rujukan}

Bastable. 2002. Prinsip-Prinsip Pengajaran dan Pembelajaran. Jakarta: EGC.

Uno, Hamzah. 2008. Toori Motivasi dan Pengukurannya. Jakarta: Bumi Aksara.

Desmita. 2009. Psikologi Perkambangan Peserta Didik. Bandung: PT Remaja Rosda karya.

Cholil \& Sugeng Kurniawan. 2011. Psikologi Pendidikan. Surabaya: IAIN Sunan Ampel Press.

Hasibuan. 2002. Proses Belajar Mengajar. Jakarta: Gramedia.
Jane, Elizabeth. 2004. Manajemen Pengembangan Diri, Organisasi Dan Perusahaan. Bandung: Nusamedia.

Munadi, Yudhi. 2012. Media Pembelajaran. Jakarta: GP Press.

Notoatmodjo, S. 2005. Metodologi Penelitian Kesehatan. Jakarta: Rineka Cipta.

Nursalam. 2008. Pendidikan Dalam Keperawatan. Jakarta: Salemba Medika.

2011. Konsep Dan Penerapan Metodologi Penelitian Ilmu Keperawatan Pedoman Skripsi, Tesis Dan Instrumen Penelitian Keperawatan Edisi 2. Jakarta: Salemba Medika.

Putra, I.S. dan Pratiwi A. 2005. Sukses dengan Soft Skills. Bandung: Direktorat Pendidikan ITB.

Robbins Stephen P, 2005. Organizational Behavior. Tweltth edition. Pearson Education International.

Robin dan Judge. 2008. Perilaku Organisasi Organizatinational Behavior Edisi 12. Jakarta: Salemba

Slameto. 1987, Belajar dan Faktor-faktor yang mempengaruhinya, Jakarta: Bina Aksara.

Slameto. 2003. Belajar dan Faktor-Faktor yang Mempengaruhinya. Jakarta: Rineka Cipta

Subini, Nini. 2012. Psikologi Pembelajaran. Jogjakarta: Mentari Pustaka.

Sudjana, Nana. 1989. Cara Belajar Siswa Aktif-Dalam Proses Belajar Mengajar. Bandung: Sinar Baru. 
Sunaryo. 2002. Psikologi untuk

Keperawatan. Jakarta: EGC.

Sunyoto. 2002. Psikologi Pendidikan. Yogyakarta: Rineka Cipta.

Tu'u,Tulus.2004. Peran Disiplin pada Perilaku dan Prestasi Siswa. Jakarta: Rineka Cipta

Yusuf, Syamsu. 2009. Psikologi prkembangan anak dan remaja. Bandung: PT Remaja Rosdakarya. 